\title{
Application of a Lumped Multi-Section Model for Analyzing the Thermal Performance of a Small-Scale Biomass Boiler
}

\section{POLESEK-KARCZEWSKA Sylwia*, WARDACH-ŚWIĘCICKA Izabela, KARDAŚ Dariusz, TURZYŃSKI Tomasz}

Renewable Energy Department, Szewalski Institute of Fluid-Flow Machinery, Polish Academy of Sciences, Fiszera 14, PL 80-231 Gdańsk, Poland

(C) The Author(s) 2021

\begin{abstract}
The stationary lumped-cell model was developed and used to simulate the thermal characteristics of domestic biomass boiler with helically coiled tube heat exchanger (HCHE). The device serves as the heat source for ORC (Organic Rankine Cycle) unit and utilizes the thermal oil as the medium transferring the heat to the unit. Most of studies available in the literature refer to the CFD simulations for water flow in tube coils or in one- or two-turn coil elements. These investigations are basically focused on the determination of Nusselt number. The proposed herein model aims at determining the thermal performance of flue gas-oil HCHE while providing low CPU time. To demonstrate the model possibilities, it was used to predict the flue gas temperatures at the inlet and outlet from the heat exchange zone, based on measurement data regarding the outlet temperature of thermal oil. Six test series were considered. The computation results appeared to be in satisfactory agreement with experimental results (the discrepancies do not exceed 12\%). The investigations showed that the used approach may be recommended as an alternative method that allows for fast prediction of thermal parameters for units of complex geometries, in particular the multi-coil heat exchangers.
\end{abstract}

Keywords: lumped cell-model, biomass boiler, helically coiled tube heat exchanger

\section{Introduction}

Due to worldwide trends towards the development of effective energy generation technologies based on renewable sources, the biomass-fueled boilers became the basic elements in modern combined heat and power generation systems, such as the one based on Organic Rankine Cycle (ORC) [1-3]. The development of ORC systems in Europe concentrates on small and medium scale modules, which are the best solution in the context of supporting the idea of distributed energy. For instance, in Europe there are approximately 30 ORC microsystems installed based on biomass, each of capacity

Received: Jun 26, 2019

AE: YAN Suying between 10 and $20 \mathrm{kWe}$ (the total capacity is $260 \mathrm{kWe}$ ) [4]. The effective and safe operation of such cogeneration installations requires predicting the performance of the boiler. This concerns basically the outlet temperature of the working medium that transfers heat to the organic medium, which circulates within the ORC section for electricity production. The reliable recognition of this parameter ensures the operability of the whole system, and thereby its controllability and flexibility. It also allows estimating if the boiler operates within the safe temperature range for the coolant. This is of particular importance in the case of using thermal oil coolant, when exceeding the permissible temperature

Corresponding author: POLESEK-KARCZEWSKA Sylwia E-mail: sylwia.polesek-karczewska@imp.gda.pl

www.springerlink.com 


\begin{tabular}{|c|c|c|c|}
\hline \multicolumn{4}{|c|}{ Nomenclature } \\
\hline$A$ & heat exchange surface $/ \mathrm{m}^{2}$ & $\dot{\Gamma}$ & gas mass rate due to combustion $/ \mathrm{kg} \cdot \mathrm{s}^{-1}$ \\
\hline$A_{\text {eff }}$ & effective heat exchange surface area $/ \mathrm{m}^{2}$ & $\eta$ & efficiency $/ \%$ \\
\hline$a_{\mathrm{g}}$ & gas absorptivity & $\lambda$ & $\begin{array}{l}\text { excess-air ratio; thermal conductivity/ } \\
\mathrm{W} \cdot \mathrm{m}^{-1} \cdot \mathrm{K}^{-1}\end{array}$ \\
\hline$c_{p}$ & specific heat at constant pressure $/ \mathrm{J} \cdot \mathrm{kg}^{-1} \cdot \mathrm{K}^{-1}$ & $\mu$ & dynamic viscosity $/ \mathrm{kg} \cdot \mathrm{m}^{-1} \cdot \mathrm{s}^{-1}$ \\
\hline$D_{\mathrm{c}}$ & diameter of coil curvature $/ \mathrm{m}$ & $v$ & kinematic viscosity $/ \mathrm{m}^{2} \cdot \mathrm{s}^{-1}$ \\
\hline$h$ & enthalpy of combustion $/ \mathrm{kJ} \cdot \mathrm{kg}^{-1}$ & $\rho$ & density $/ \mathrm{kg} \cdot \mathrm{m}^{-3}$ \\
\hline$L$ & coil segment length $/ \mathrm{m}$ & $\sigma$ & Stefan-Boltzmann constant $/ \mathrm{W} \cdot \mathrm{m}^{-2} \cdot \mathrm{K}^{-4}$ \\
\hline$L_{z}$ & radius of half-sphere gas volume $/ \mathrm{m}$ & $\varphi$ & coil pitch $/ \mathrm{m}$ \\
\hline$M$ & molar mass $/ \mathrm{kg} \cdot \mathrm{kmol}^{-1}$ & \multicolumn{2}{|c|}{ Subscripts/Superscript } \\
\hline $\bar{M}_{\text {mix }}$ & molar mass of gas mixture $/ \mathrm{kg} \cdot \mathrm{kmol}^{-1}$ & $\mathrm{ad}$ & adiabatic \\
\hline$m$ & mass $/ \mathrm{kg}$ & $\mathrm{CH}$ & chemical \\
\hline$\dot{m}$ & mass rate $/ \mathrm{kg} \cdot \mathrm{s}^{-1}$ & $\mathrm{c}$ & convection \\
\hline$p$ & gas pressure/Pa & $\mathrm{db}$ & dry basis \\
\hline$p_{\mathrm{H}_{2} \mathrm{O}}$ & steam partial pressure $/ \mathrm{kPa}$ & $\mathrm{g}$ & gas (flue gases) \\
\hline$Q$ & heat $/ J$ & $i$ & calculation cell number \\
\hline$\dot{Q}$ & heat flux/W & in & inlet \\
\hline$T$ & temperature/K & inn & inner \\
\hline$t$ & time/s & $j$ & coil number \\
\hline$X$ & mole fraction $/ \mathrm{mol} \cdot \mathrm{mol}^{-1}$ & 1 & liquid (oil) \\
\hline \multicolumn{2}{|c|}{ Greek symbols } & o & outer \\
\hline$\alpha$ & heat transfer coefficient $/ \mathrm{W} \cdot \mathrm{m}^{-2} \cdot \mathrm{K}^{-1}$ & out & outlet \\
\hline$\alpha_{n}$ & $\begin{array}{l}\text { heat transfer coefficient for straight tube/ } \\
\mathrm{W} \cdot \mathrm{m}^{-2} \cdot \mathrm{K}^{-1}\end{array}$ & $\mathrm{r}$ & radiation \\
\hline$\beta$ & correction factor & $\mathrm{s}^{*}$ & stoichiometric \\
\hline$\beta_{\varepsilon}$ & correction factor for steam pressure & $\mathrm{w}$ & wall \\
\hline$\varepsilon^{\prime}$ & effective emissivity & 1 & inner coaxial coil \\
\hline$\varepsilon_{\mathrm{g}}$ & gas emissivity & 2 & outer coaxial coil \\
\hline
\end{tabular}

limits leads to its degradation and loss of properties. The possible routes to simulate the thermal performance of the boilers is to use advanced CFD-based calculations that involve the solution of such phenomena as fluid flow, phase change, chemical reactions or heat transfer, or to utilize lumped models. However, in the case of complex geometry of heat exchange part of the boiler, CFD simulations meet many difficulties and are timeconsuming, which is not effective from practical point of view. This is, for instance, the case for coil-type heat exchangers. Helically coiled heat exchangers are of common interest in many industrial applications, including energy systems, since they can provide large heat transfer areas in relatively small volume. Compared to straight pipe, they are characterized by higher heat transfer rate and pressure drop [5-7]. Therefore, they have been extensively studied for decades. However, the majority of research focuses on liquid flow and heat transfer characteristics inside the coiled tube. These include the latest numerical simulations [8-11] and experimental studies on the flow in the helically coiled tubes $[6,12-14]$, in the annulus of concentric helical coils [15] or in a double-pipe helical heat exchanger [16, 17]. The thermal performance of coil-type heat exchanger for gas media was analysed, for instance, by Clay and Tansley [18] who performed the CFD calculation for tube-in-tube micro gas turbine recuperator of maximum capacity $1 \mathrm{~kW}$ for micro-CHP (combine heat and power) unit. However, the literature lacks the investigation results in the field of thermal analysis of coil-type heat exchange section in small and medium-scale biomass-fired boilers, which are based on the in-house codes and could be useful in the design and verification of preliminary geometry. Sogni and Chiesa [19] developed the one-dimensional model for thermal rating of helically coiled heat recovery boilers fed with exhaust gases, however it was applied to improve the design of two models of large-scale thermal oil boiler 
(504 and $772 \mathrm{~kW}$ ). Hassanzadeh et al. [20] simulated the operation of the large-scale steam generator applying zonal modelling and proposed $\mathrm{Nu}$ number correlation for flow inside and outside the coil. Other available works regard basically the CFD simulations and focus on the characteristics of fuel bed combustion and flue gas composition [21-23].

We aimed at the analysis of thermal performance of domestic biomass boiler with the helically coiled heat exchange part and the thermal oil as the cooling medium. Since the heating unit was designed to work with the ORC power generation system, the general goal of the study was to develop the fast calculation tool for predicting the thermal parameters of boiler media. Due to complex geometry of heat exchange boiler section, it was decided to apply lumped cell-model. This approach, in spite of many simplifications needed to be assumed, is far simpler and of satisfactory accuracy, particularly in the case of small-scale boilers. To validate the calculation method, the computation results were compared with the measurement data derived from the laboratory-scale biomass boiler.

\section{Laboratory Helical Coil Boiler}

The boiler unit itself consists of a coaxial, double helical coil as the heat exchanger and a retort-type biomass burner (located at the bottom of the unit), connected with a small biomass reservoir. In this particular installation, thermal oil is used as the heating agent due to high output temperature parameters under atmospheric pressure. The general diagram of micro CHP ORC installation with biomassfired boiler is presented in Fig. 1. The more detailed draft of studied boiler indicating the flow directions of flue gases and cooling media is shown in Fig. 2. The hot flue gases flow from the burner upwards along the smaller coil, then, at the top of the boiler, change direction and flow downward between both coils, and finally flow up to the boiler's stack. On the other hand, the thermal oil inlet is located at the bottom of the outer (wider) helical coil. The oil travels up in the outer coil and then down to the outflow in the inner coil.

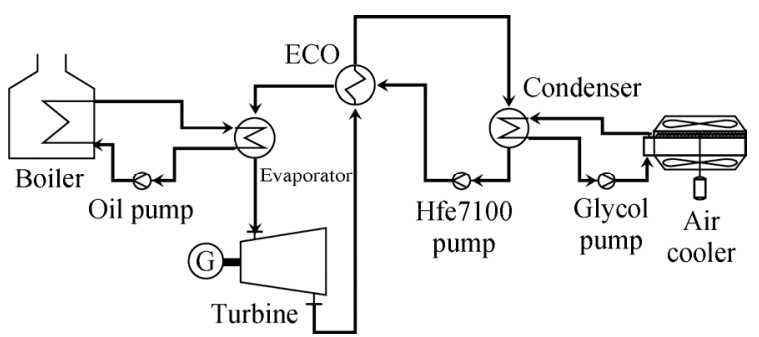

Fig. 1 The layout of ORC system supplied by biomass-fueled boiler (ECO: economizer (plate heat exchanger); G: generator)
Spiral tube heat exchanger prevents thermal oil from overheating, which could have taken place for instance in a shell-type exchanger. Overheated thermal oil tends to drastically change its properties and can even choke the flow through the accumulation of deposits.

The construction of the burner system consists of a fuel reservoir connected to the screw conveyor that transports the fuel to the main burner located at the bottom of the boiler unit. The main burner section is shaped as a reversed truncated cast iron cone with air inlets placed annular near the wider edge. This construction results in a fuel bed with primary air being delivered from beneath it and thus creating a steady symmetrical flame that allows the thermal oil in the smaller coil to heat up evenly and prevents the accelerated wear of the heat exchanger.

(a)

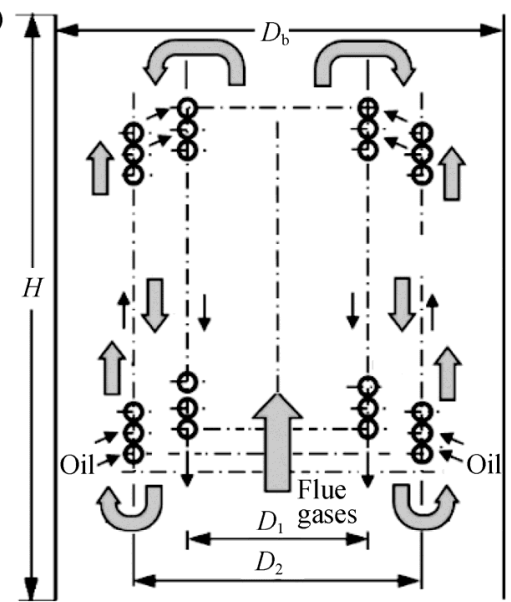

(b)

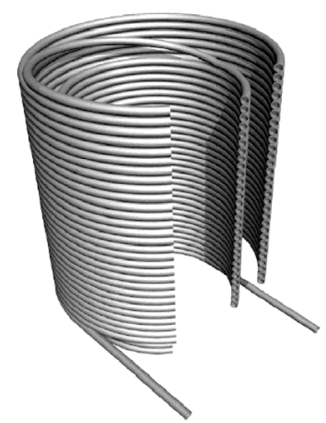

Fig. 2 An arrangement diagram of the studied coil-type boiler: the media flow directions (a) [24] and the 3-D part view of the heat exchange section $(\mathrm{b})\left(D_{\mathrm{b}}\right.$ : boiler outer diameter, $H$ : boiler height, $D_{1}$ : inner-coil diameter, $D_{2}$ : outer coil diameter)

Used measurement system enables the boiler unit to work without cooperation with ORC section. In presented herein experimental research, the heat from thermal oil is transferred to ethylene glycol solution in a shell-coil type exchanger and cooled in air cooler. In this configuration, it is possible to measure thermal balance in terms of fuel, oil and air mass flows. 
In this type of a burner, both air and fuel are being transported to the boiler as premixed bed. The mass flow of fuel is estimated as the statistical mass of fuel transferred by the feed screw of the retort burner at a given working time and standby time setting of the feeder. The inlet air flow is measured on straight pipe segment between the burner and the fan with the use of thermal flow meter. This device is powered from external $24 \mathrm{~V}$ power supply and gives the signal of $4 \mathrm{~mA}$ to $20 \mathrm{~mA}$. The similar flow meter is installed in the stack for flue gas flow measurement.

The mass flow of thermal oil is being measured at the outlet from the boiler using a GPI GBT-075Hx-x 3/4" turbine flow meter. These types of flow meters are very sensitive to viscosity. However, due to moderate and high temperatures, the oil viscosity drops dramatically, which provides the proper turbine work.

Temperatures of flue gas are measured in four distinct points. The first one is located in the main stream right above the burner. To ensure stable measurement in aggressive environment, a corundum C799 coated S-type fireproof thermocouple is used. The second and third points of measurement are situated between the inner and the outer coil and near the boiler wall, respectively. In both cases, K-type thermocouples are used. The last measurement point is located inside the stack, where the gas analyzer sensor is used. Additionally, the temperatures of thermal oil at the inlet and the outlet are also measured using K-type thermocouples. The details on the range and accuracy of measuring devices are given in Table 1.

Table 1 Characteristics of used measuring instruments

\begin{tabular}{ccc}
\hline & Range & Accuracy \\
\hline Air flow meter & 0 to $200 \mathrm{~kg} / \mathrm{h}$ & $\pm 1.0 \mathrm{~kg} / \mathrm{h}$ \\
Oil flow meter & 0 to $1300 \mathrm{~kg} / \mathrm{h}$ & $\pm 0.5 \%$ \\
S-type sensor & $0^{\circ} \mathrm{C}$ to $1100^{\circ} \mathrm{C}$ & $\pm 1.0^{\circ} \mathrm{C}$ \\
& $1100^{\circ} \mathrm{C}$ to $1600^{\circ} \mathrm{C}$ & $\pm(1+0.003(T-1100))^{\circ} \mathrm{C}$ \\
K-type sensor & $-200^{\circ} \mathrm{C}$ to $1200^{\circ} \mathrm{C}$ & $\pm 1.5^{\circ} \mathrm{C}$ \\
\hline
\end{tabular}

\section{Mathematical Model of Coil Type Heat Exchanger: A Unified Approach}

For the purpose of thermal-flow simulations, the unified model for energy balance of the multi-coil system is proposed. As shown in Fig. 3, which represents the cross-section of a system limited to four coils, the model assumes that each control volume includes the paired flue gas flow channel and the coil with the oil flow in-side. Contrary to the center coils $\left(S_{1}\right.$ to $\left.S_{3}\right)$, which form the lateral surfaces of the flue gas channels, the outer-most coil $\left(S_{4}\right)$ is considered to be situated in the middle of the gas channel. Such configuration leads to the countercurrent flow type of media in each balance section.

In the proposed approach, it is assumed that, within each control volume, the single coil element and gas volume paired with it, constitute the single computational cell. For each $i$-th numerical cell, $i=1, . .,\left(N_{1}+N_{2}+\ldots+N_{j}\right)$, where $N_{j}$ (e.g. according to Fig. $3, j=4$ ) denotes the number of segments of subsequent coil $\left(N_{1}\right.$ refers to the most inner one), the mass and energy balance equations for gas and liquid sides are considered. The diagram showing the energy balance for $i$-th cell for the studied counter-current flow case (the example cell is marked with blue outline in Fig. 3) is presented in Fig. 4. The energy balance for the gas (hot)-side accounts for the heat fluxes: (i) supplied by flue gases flowing into the section $\dot{Q}_{\mathrm{g}, i}^{\text {in }}$, (ii) abstracted due to gas outflow $\dot{Q}_{\mathrm{g}, i}^{\text {out }}$, (iii) generated in chemical reactions $\left(\dot{Q}_{\mathrm{g}, \mathrm{CH}}\right)_{i}$, (iv) emitted by gas volume through radiation $\left(\dot{Q}_{\mathrm{g}, \mathrm{r}}\right)_{i}$ and (v) transferred to the coil tube wall by convection $\left(\dot{Q}_{\mathrm{g}, \mathrm{c}}\right)_{i}$. Similarly, the energy balance for the oil-side takes into consideration the heat fluxes transferred by oil inflow and outflow, $\dot{Q}_{1, i}^{\text {in }}$ and $\dot{Q}_{1, i}^{\text {out }}$, respectively, as well as the wall radiation $\left(\dot{Q}_{\mathrm{l}, \mathrm{r}}\right)_{i}$ and wall-to-liquid convection $\left(\dot{Q}_{\mathrm{l}, \mathrm{c}}\right)_{i}$. The-governing equations for the system are summarized in Table 2.

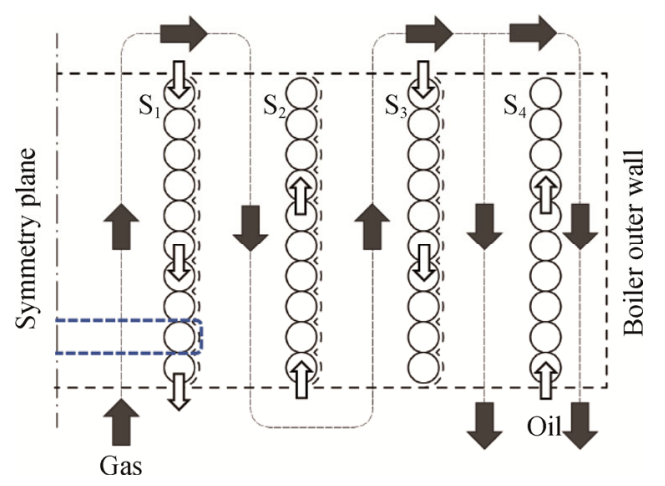

Fig. 3 A general schematic diagram of balancing the helical multi-coil heat exchanger (dashed lines mark the control volumes)

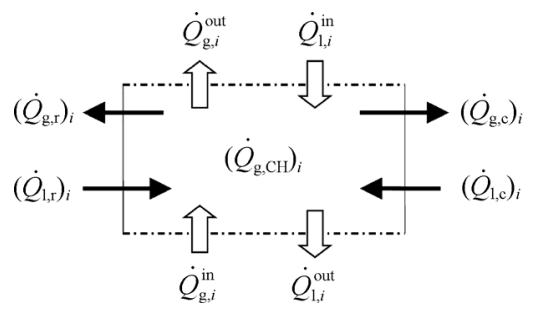

Fig. 4 Energy balance scheme for $i$-th cell (lumped-cell model for counter-current flow case) 
Table 2 Governing equations

\begin{tabular}{|c|c|c|}
\hline \multicolumn{3}{|c|}{ Flue gas-side } \\
\hline Mass: & $\dot{m}_{\mathrm{g}}^{\text {in }}+\dot{\Gamma}_{i}-\dot{m}_{\mathrm{g}}^{\text {out }}=0$ & (G.1) \\
\hline \multirow[t]{8}{*}{ Energy: } & $\dot{Q}_{\mathrm{g}, i}^{\text {in }}-\dot{Q}_{\mathrm{g}, i}^{\text {out }}+\left(\dot{Q}_{\mathrm{g}, \mathrm{CH}}\right)_{i}-\left(\dot{Q}_{\mathrm{g}, \mathrm{r}}\right)_{i}-\left(\dot{Q}_{\mathrm{g}, \mathrm{c}}\right)_{i}=0$ & (G.2) \\
\hline & \multicolumn{2}{|l|}{ where: } \\
\hline & $\dot{Q}_{\mathrm{g}}^{\text {in }}=\dot{m}_{\mathrm{g}}^{\text {in }} c_{p, \mathrm{~g}}\left(T_{\mathrm{g}, i}\right) T_{\mathrm{g}}^{\text {in }}$ & (G.2a) \\
\hline & $\dot{Q}_{\mathrm{g}}^{\text {out }}=\dot{m}_{\mathrm{g}}^{\text {out }} c_{p, \mathrm{~g}}\left(T_{\mathrm{g}, i}\right) T_{\mathrm{g}}^{\text {out }}$ & (G.2b) \\
\hline & $\left(\dot{Q}_{\mathrm{g}, \mathrm{CH}}\right)_{i}=\dot{\Gamma}_{i} h_{i}$ & (G.2c) \\
\hline & $\left(\dot{Q}_{\mathrm{g}, \mathrm{r}}\right)_{i}=A \varepsilon_{\mathrm{w}}^{\prime} \sigma\left(\varepsilon_{\mathrm{g}, i} T_{\mathrm{g}, i}^{4}-a_{\mathrm{g}, i} T_{\mathrm{w}, i}^{4}\right)$ & (G.2d) \\
\hline & $\left(\dot{Q}_{\mathrm{g}, \mathrm{c}}\right)_{i}=\alpha_{\mathrm{g}, i} A\left(T_{\mathrm{g}, i}-T_{\mathrm{w}, i}\right)$ & (G.2e) \\
\hline & \multicolumn{2}{|l|}{ Oil-side } \\
\hline Mass: & $\dot{m}_{1}^{\text {in }}-\dot{m}_{1}^{\text {out }}=0$ & (L.1) \\
\hline \multirow[t]{6}{*}{ Energy: } & $\dot{Q}_{1, i}^{\text {in }}-\dot{Q}_{1, i}^{\text {out }}+\left(\dot{Q}_{1, \mathrm{r}}\right)_{i}+\left(\dot{Q}_{1, \mathrm{c}}\right)_{i}=0$ & (L.2) \\
\hline & where: & \\
\hline & $\dot{Q}_{1}^{\text {in }}=\dot{m}_{1}^{\text {in }} c_{p, 1}\left(T_{1, i}\right) T_{1}^{\text {in }}$ & (L.2a) \\
\hline & $\dot{Q}_{1}^{\text {out }}=\dot{m}_{1}^{\text {out }} c_{p, 1}\left(T_{1, i}\right) T_{1}^{\text {out }}$ & (L.2b) \\
\hline & $\left(\dot{Q}_{1, \mathrm{r}}\right)_{i}=A \varepsilon_{\mathrm{w}} \sigma\left(T_{\mathrm{w}, i}^{4}-T_{1, i}^{4}\right)$ & (L.2c) \\
\hline & $\left(\dot{Q}_{1, \mathrm{c}}\right)_{i}=\alpha_{1, i} A\left(T_{\mathrm{w}, i}-T_{1, i}\right)$ & (L.2d) \\
\hline
\end{tabular}

Here, $\dot{\Gamma}_{i}$ represents the gas mass flux generated in result of fuel oxidation. This is assumed to take place in the cell $i=0$, which implies:

$$
\dot{\Gamma}_{i}=0 \text { for } i \neq 0
$$

The combustion temperature calculated for the " 0 " cell represents the heat exchanger inlet flue gas temperature and constitutes the initial simulation condition.

Quantity $\varepsilon^{\prime}{ }_{\mathrm{w}}$ in Eq. (G.2d) denotes the effective emissivity of the wall (barrier) being defined as $\varepsilon_{\mathrm{w}}^{\prime}=\left(\varepsilon_{\mathrm{W}}+1\right) / 2$, where $\varepsilon_{\mathrm{w}}$ is the wall emissivity. The wall temperature is computed according to the heat balance between the media:

$$
\dot{m}_{\mathrm{g}} c_{p, \mathrm{~g}}\left(T_{\mathrm{g}}-T_{\mathrm{w}}\right)=\dot{m}_{1} c_{p, 1}\left(T_{\mathrm{w}}-T_{1}\right)
$$

which yields:

$$
T_{\mathrm{w}}=\frac{G T_{\mathrm{g}}+T_{1}}{1+G}, G=\frac{\dot{m}_{\mathrm{g}} c_{p, \mathrm{~g}}}{\dot{m}_{1} c_{p, 1}}
$$

The problem studied leads to the solution of system of two equations (G.2) and (L.2) with unknown temperatures $T_{\mathrm{g}}^{\text {in }}, T_{\mathrm{g}}^{\text {out }}, T_{1}^{\text {in }}$ and $T_{1}^{\text {out }}$. The system is non-linear due to form of radiation heat fluxes between hot gases and cooling oil, (Eqs. (G.2d) and (L.2c)). The problem solution requires to assume two of the unknowns. To solve the given equation system, the Newton method was adopted [25].

\subsection{Physico-chemical properties}

Ultimate and proximate analyses of wood pellets used in experiments are summarized in Table 3 . Basing on the ultimate analysis, the stoichiometric air to fuel mass ratio $\lambda_{\mathrm{s}}^{*}$ may be determined [24]. Thus, knowing the mass flow rates of air and fuel, the excess-air ratio is estimated as:

$$
\lambda=\frac{1}{\lambda_{\mathrm{s}}^{*}} \frac{\dot{m}_{\mathrm{air}}^{\text {in }}}{\dot{m}_{\text {fuel }}^{\text {in }}}
$$

The flue gas temperature at the inlet into the heat exchange zone was iteratively computed as an adiabatic combustion temperature from the energy balance given in form:

$$
\dot{Q}_{\mathrm{g}}^{\text {in }}+\dot{Q}_{\mathrm{CH}}=\dot{Q}_{\mathrm{g}}^{\text {out }}
$$

which yields:

$$
\dot{m}_{\mathrm{g}}^{\text {in }} c_{p, \mathrm{~g}}\left(T_{\mathrm{g}, i}\right) T_{\mathrm{g}, i}^{\mathrm{in}}+\dot{\Gamma} \cdot \mathrm{HHV}=\left(\dot{m}_{\mathrm{g}}^{\text {in }}+\dot{\Gamma}\right) c_{p, \mathrm{~g}}\left(T_{\mathrm{ad}}\right) T_{\mathrm{ad}}
$$

To calculate physical properties of exhaust gases, the fixed mixture composition is employed (Table 4). The specific heat is thus estimated using the formula:

$$
c_{p}(T)=\frac{a+b T+c T^{2}+\frac{d}{T^{2}}}{\frac{1}{1000} \bar{M}_{\text {mix }}}
$$

where $\bar{M}_{\text {mix }}$ denotes molar mass of gas mixture, whereas coefficients $a, b, c, d$ are based on a simple mole fraction average, i.e. $a=\sum_{i} a_{i} X_{i}$, where $X_{i}$ represents mole fraction of $i$-th gas component. The mixture thermal conductivity is a function of chemical composition and temperature, and is calculated based on mole fraction average of the pure species conductivities:

$$
\lambda_{\mathrm{g}}(T)=\sum_{i=1}^{4} \frac{X_{i} \lambda_{\mathrm{g}, i}(T)}{\sum_{j=1}^{4} X_{j} \phi_{i, j}}
$$

where

$$
\lambda_{\mathrm{g}, i}(T)=a_{i, \lambda} T+b_{i, \lambda}
$$

and

$$
\phi_{i, j}=\frac{\left[1+\left(\frac{\mu_{i}}{\mu_{j}}\right)^{1 / 2}\left(\frac{M_{i}}{M_{j}}\right)^{1 / 4}\right]^{2}}{\left[8\left(1+\frac{M_{i}}{M_{j}}\right)\right]^{1 / 2}}
$$

where $\mu_{i}$ and $M_{i}$ denote dynamic viscosity and molar mass of $i$-th component, respectively. The values of dynamic viscosity were adopted from Ref. [28]. The respective coefficients for calculation of the specific heat of flue gas (Eq. (6)) and its thermal conductivity (Eqs. (7) and (8)) are given in Table 4. For gas dynamic viscosity, the 3 rd order temperature-dependent polynomial 
approximating tabulated data for air were used [24]. The gas density was determined applying the Clapeyron equation:

$$
\rho_{\mathrm{g}}=\frac{p}{R_{\text {ind }} T}
$$

where $R_{\text {ind }}$ is the individual gas constant for gas mixture in the unit of $\mathrm{J} \cdot \mathrm{kg}^{-1} \cdot \mathrm{K}^{-1}$, whereas $p$ denotes pressure. Subscript "ind" is the abbreviation of "individual". In the case of oil, the linear temperature-dependent functions (for temperature in the unit of K) for its density, specific heat and thermal conductivity were adopted, as shown, respectively [30]:

$$
\begin{gathered}
\rho_{1}=-0.650 T+1053.589 \\
c_{p, 1}=3.594 T+830.934 \\
\lambda_{1}=-0.0001 T+0.1555
\end{gathered}
$$

whereas its kinematic viscosity is described by power-type function:

$$
v_{1}= \begin{cases}a_{1} T+b_{1} & \text { for } T \leq 313 \mathrm{~K} \\ a_{2} T^{b_{2}} & \text { for } T>313 \mathrm{~K}\end{cases}
$$

with coefficients $a_{1}, b_{1}, a_{2}, b_{2}$ determined based on the manufacturer's data [30].

Table 3 Ultimate and proximate analyses of wood pellets [26]

\begin{tabular}{cccc}
\hline \multicolumn{2}{c}{ Ultimate analysis/wt $\%_{\mathrm{db}}$} & \multicolumn{2}{c}{ Proximate analysis $/ \mathrm{wt} \%$} \\
\hline Carbon & 48.50 & Volatile matter & 71.55 \\
Hydrogen & 5.30 & Fixed carbon & 20.28 \\
Oxygen & 45.78 & Moisture & 6.10 \\
Nitrogen & 0.40 & Ash & 2.07 \\
Sulphur & 0.02 & HHV $^{*}$ & 18.28 \\
\hline
\end{tabular}

*Derived according to Ref. [27]

Table 4 Coefficients for Eqs. (6) and (8) [29]

\begin{tabular}{lcccc}
\hline & $\mathrm{H}_{2} \mathrm{O}$ & $\mathrm{CO}_{2}$ & $\mathrm{O}_{2}$ & $\mathrm{~N}_{2}$ \\
\hline$a_{i} / \mathrm{J} \cdot \mathrm{mol}^{-1} \cdot \mathrm{K}^{-1}$ & 30.13 & 44.15 & 36.17 & 27.83 \\
$b_{i} / 10^{-3} \mathrm{~J} \cdot \mathrm{mol}^{-1} \cdot \mathrm{K}^{-2}$ & 11.30 & 9.04 & 0.84 & 4.18 \\
$c_{i} / 10^{-6} \mathrm{~J} \cdot \mathrm{mol}^{-1} \cdot \mathrm{K}^{-3}$ & 0 & 0 & 0 & 0 \\
$d_{i} / \mathrm{J} \cdot \mathrm{K} \cdot \mathrm{mol}^{-1}$ & 0 & -8.54 & -4.13 & 0 \\
$a_{i, \lambda} / 10^{-6} \mathrm{~W} \cdot \mathrm{m}^{-1} \cdot \mathrm{K}^{-2}$ & 85.20 & 68.90 & 65.15 & 56.01 \\
$b_{i, \lambda} / 10^{-4} \mathrm{~W} \cdot \mathrm{m}^{-1} \cdot \mathrm{K}^{-1}$ & 110.78 & 34.87 & 78.63 & 83.41 \\
\hline
\end{tabular}

\subsection{Convection parameters}

A single coil element is schematically shown in Fig. 5. For the purpose of our studies, the tube is assumed to be thin-walled, thus $d_{\mathrm{o}}=d_{\mathrm{inn}}=d$. The diameter of curvature $D_{\text {c }}$ for $j$-th coil is given by:

$$
D_{\mathrm{c}}=\sqrt{\varphi^{2} / 4+D^{2}}
$$

where $D$ is the coil annulus diameter and $\varphi$ denotes the coil pitch. The segment length of $j$-th coil is thus expressed as:

$$
L=\pi \sqrt{\varphi^{2}+D^{2}}
$$

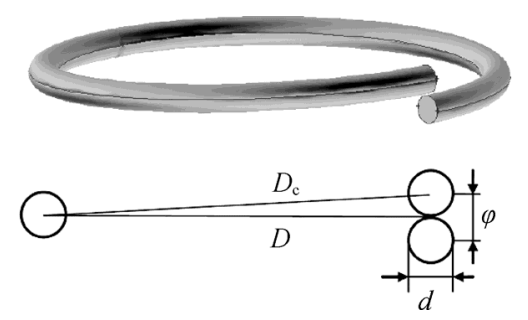

Fig. 5 The helical coil segment: 3D view (top) and the cross-section (bottom)

In general, the heat transfer coefficient is a function of flow characteristics, defined by Nusselt number, the characteristic flow dimension $d$ and the thermal conductivity of flowing medium $\lambda$ :

$$
\alpha=\frac{N u \cdot \lambda}{d}, N u=f(R e, P r)
$$

Obviously, the characteristic dimension for flow of oil is the tube diameter, while for flue gas flow it is the equivalent diameter. In the studied case, the heat transfer coefficient on exhaust gas-side $\alpha_{\mathrm{g}}$ is difficult to estimate due to complex geometry of heat recovery section. Here, the Nusselt number given by Reiher and Hilpert correlation for a single pipe in a cross-flow was adopted:

$$
N u_{\mathrm{g}}=C \cdot R e^{n}
$$

with coefficients $C$ and $n$ dependent on Reynolds number [31]. The Reynolds number is based on gas velocity, which is expressed as:

$$
v_{\mathrm{g}}=\frac{\dot{m}_{\mathrm{g}}}{A_{\mathrm{g}} \rho_{\mathrm{g}}}
$$

where $A_{\mathrm{g}}$ is the cross-sectional area for exhaust gas flow.

To predict the Nusselt number for the flow of oil in a coiled tube of inner-diameter $d$ and length $L$, the following relationships were utilized [31, 32]:

for laminar flow $(R e<2100)$ :

$$
N u_{1}=\left\{\begin{array}{c}
1.8\left(\frac{\mu}{\mu_{\mathrm{w}}}\right)^{0.14}\left(\operatorname{Re} \operatorname{Pr} \frac{d}{L}\right)^{\frac{1}{3}}, \text { for }\left(\operatorname{Re} \operatorname{Pr} \frac{d}{L}\right)>13 \\
0.5 \operatorname{Re} \operatorname{Pr}\left(\frac{d}{L}\right), \text { for }\left(\operatorname{Re} \operatorname{Pr} \frac{d}{L}\right)<4.5
\end{array}\right.
$$

for fully developed turbulent flow $\left(\operatorname{Re}>10^{4}\right)$ :

$$
N u_{1}=0.027\left(\frac{\mu}{\mu_{\mathrm{w}}}\right)^{0.14} \operatorname{Re}^{0.8} \operatorname{Pr}^{\frac{1}{3}}
$$

for the transition region $\left(2100 \leq R e \leq 10^{4}\right)$ :

$$
N u_{1}=0.00069 \operatorname{Re}^{1.24} \operatorname{Pr}^{0.5}
$$

where $\mu$ denotes dynamic viscosity determined for an 
average medium temperature. Subscript "w" refers to the value determined at the wall temperature. Additionally, due to coil curvature the correction for heat transfer coefficient was taken into account [24], which is given in form:

$$
\alpha=\alpha_{n}\left(1+3.54 \frac{d}{D_{\mathrm{c}}}\right)
$$

where $\alpha_{n}$ denotes the heat transfer coefficient for straight tube.

\subsection{Gas radiation}

The radiative properties of flue gases, emissivity $\varepsilon_{\mathrm{g}}$ and absorptivity $a_{\mathrm{g}}$, are calculated for given content of radiating gas components, e.g. $\mathrm{CO}_{2}$ and $\mathrm{H}_{2} \mathrm{O}$ (for further details see Table 4), adopting the expressions:

$$
\varepsilon_{\mathrm{g}}=\varepsilon_{\mathrm{CO}_{2}}+\beta_{\varepsilon} \varepsilon_{\mathrm{H}_{2} \mathrm{O}}-\varepsilon_{\mathrm{CO}_{2}} \beta_{\varepsilon} \varepsilon_{\mathrm{H}_{2} \mathrm{O}}
$$

and

$$
a_{\mathrm{g}}=\varepsilon_{\mathrm{CO}_{2}}\left(\frac{T_{\mathrm{g}}}{T_{w}}\right)^{0.65}+\beta \varepsilon_{\mathrm{H}_{2} \mathrm{O}}-\Delta \varepsilon_{\mathrm{g}}
$$

where $\beta$ is the correction factor that accounts for higher concentration of steam in flue gases and $\Delta \varepsilon_{\mathrm{g}}$ is the correction factor due to mutual absorption of energy emitted by different radiating gases [31]. Quantity $\beta_{\varepsilon}$ represents the correction factor that accounts for an influence of water steam pressure:

$$
\beta_{\varepsilon}=1+\left[0.6225-0.1346 \ln \left(\frac{p_{\mathrm{H}_{2} \mathrm{O}} L_{z}}{1 \mathrm{kPa} \cdot \mathrm{m}}\right)\right]\left(\frac{p_{\mathrm{H}_{2} \mathrm{O}}}{100 \mathrm{kPa}}\right)
$$

where $L_{z}$ is the radius of half-sphere gas volume. Instead of radius $L$, we introduced the substitute gas layer thickness that defines the semi-circle radiating gas volume $L_{z}=4 V / S$, where $V$ and $S$ denote the volume and the total outer surface of the gas volume, respectively. The emissivity values for both radiating components were determined based on Hottel's graphs [31, 33].

\section{Calculation Results}

The calculation required to determine the heat exchange surface area. It appeared that due to the specific design of the boiler, not all the surface of coil tube takes part in the heat exchange process. Hence, the first step was to estimate the effective heat exchange surface area $A_{\text {eff }}$ [24]. To do so, the 2D stationary case of steel pipes mounted in flue gas cross-flow bounded by rectangular sized $0.1 \mathrm{~m} \times 0.3 \mathrm{~m}$ was simulated using Ansys Fluent. The tube diameter was set to $d=0.027 \mathrm{~m}$ and its temperature to $150^{\circ} \mathrm{C}$. The temperature of the bounding walls was assumed to maintain at $600^{\circ} \mathrm{C}$.

The thermo-physical properties of pipe wall, used in computation are: density $\rho_{\mathrm{s}}=8030 \mathrm{~kg} \cdot \mathrm{m}^{-3}$, specific heat $c_{p, \mathrm{~s}}=503 \mathrm{~J} \cdot \mathrm{kg}^{-1} \cdot \mathrm{K}^{-1}$ and thermal conductivity $\lambda_{\mathrm{s}}=16.27$
$\mathrm{W} \cdot \mathrm{m}^{-1} \cdot \mathrm{K}^{-1}$. The assumed average inflow flue gas velocity was $v_{\mathrm{g}}=0.44 \mathrm{~m} \cdot \mathrm{s}^{-1}$, which represented the mass flow rate at the level of $\dot{m}_{\mathrm{g}}=0.0122 \mathrm{~kg} \cdot \mathrm{s}^{-1}$. The $k-\varepsilon$ turbulence model was applied. The resulting temperature field is reproduced in Fig. 6. It is clearly seen that only a part of the pipe surface is participating in the heat exchange process, which is a consequence of gas velocity decrease in spaces between the pipes. The tube lateral side taking part in the process is displayed in a magnified cross-section by circle arcs (marked in brown), in Fig. 6 . The angle that delineates the effective surface was estimated to $64^{\circ}$, which leads to:

$$
A_{\text {eff }}=\frac{A}{2.8}
$$

where $A$ is the total coil lateral surface.

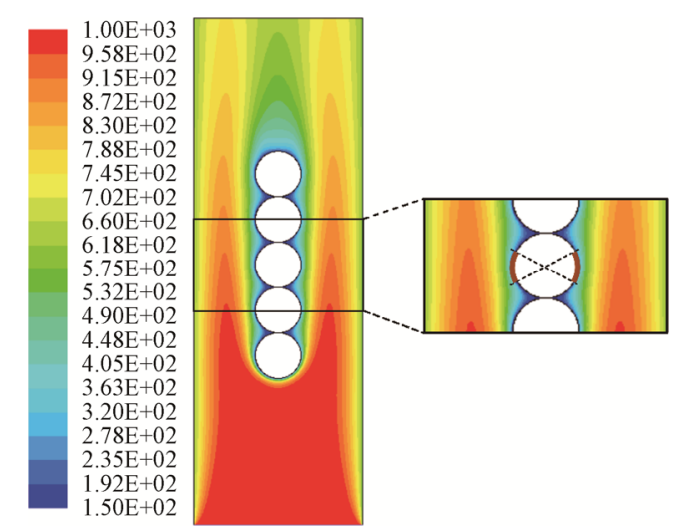

Fig. 6 The simulated temperature field (in the unit of K)

\subsection{Computation example: four-coil heat exchanger}

The developed calculation method was first applied to the general test case of the HCHE (helically coiled tube heat exchanger) composed of four coils - the one, which is schematically shown in Fig. 3. It is assumed that each coil consists of 28 segments. The input computation parameters for the test case, including the geometry dimensions, the media mass flow rates and the oil temperature at the heat exchanger outlet and the flue gas mole fraction are presented in Table 5.

The flue gas temperature at the inlet into the heat recovery section was assumed adiabatic, $T_{\mathrm{g}}^{\text {in }}=T_{\mathrm{ad}}$, which equals approximately $1230^{\circ} \mathrm{C}$. Additionally, the outlet oil temperature $T_{1}^{\text {out }}$ was set to upper limit of $300^{\circ} \mathrm{C}$. The calculated temperature changes of the media are shown in Fig. 7. In the figure the input temperatures are also marked (points). As observed, the temperature gradients for both media, are the greatest in the first (annular) section and decreases in each subsequent coil. The heat efficiency of the coil sections are approximately 
$7.0,4.2,1.3$ and $0.1 \mathrm{~kW}$, which gives the total capacity of $\sim 12.6 \mathrm{~kW}$. This provides that in this case the last section is inefficient and economically unjustified.

Table 5 Input calculation data - test case

\begin{tabular}{cccc}
\hline Parameter & Value & Parameter & Value \\
\hline$D_{b} / \mathrm{m}$ & 0.83 & $\dot{m}_{\text {fuel }} / \mathrm{kg} \cdot \mathrm{h}^{-1}$ & 5 \\
$H / \mathrm{m}$ & 0.81 & $\dot{m}_{\text {air }} / \mathrm{kg} \cdot \mathrm{h}^{-1}$ & 50.0 \\
$D_{1} / \mathrm{m}$ & 0.29 & $\dot{m}_{1} / \mathrm{kg} \cdot \mathrm{h}^{-1}$ & 750.0 \\
$D_{2} / \mathrm{m}$ & 0.43 & $T_{1}^{\text {out }} /{ }^{\circ} \mathrm{C}$ & 300.0 \\
$D_{3} / \mathrm{m}$ & 0.57 & Flue gas composition $(\mathrm{vol} \%)$ \\
\cline { 3 - 4 }$D_{4} / \mathrm{m}$ & 0.71 & $\mathrm{H}_{2} \mathrm{O} / \%$ & 7.51 \\
$d / \mathrm{m}$ & 0.027 & $\mathrm{CO}_{2} / \%$ & 10.09 \\
$\varphi / \mathrm{m}$ & 0.027 & $\mathrm{O}_{2} / \%$ & 9.54 \\
$N_{i}, i=1, . .4$ & 28 & $\mathrm{~N}_{2} / \%$ & 72.86 \\
\hline
\end{tabular}

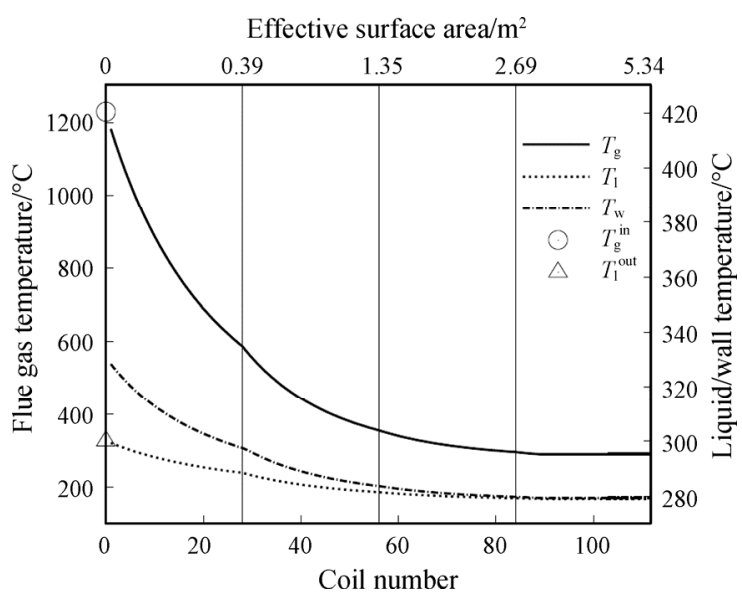

Fig. 7 The simulated media temperature changes for the test case

\subsection{Application of the model to real case of double HCHE}

The proposed herein lumped-cell model was then used to study the thermal performance of laboratory scale heat recovery section of biomass-fired boiler combined with ORC module. The computation inputs covered the section geometry, the flow rates of media (i.e. oil, air, fuel), fuel composition and outlet oil temperature $T_{1}^{\text {out }}$. The geometrical data of the boiler used in simulations are summarized in Table 6. Given these dimensions, the total coil surface area $A$ amounts to $7.74 \mathrm{~m}^{2}$, which in accordance with the aforementioned analysis comes down to the effective heat exchange surface area of $A_{\text {eff }}=2.87 \mathrm{~m}^{2}$.

The experimental thermal and flow data for the laboratory-scale boiler are shown in Table 7. These also include the temperature of flue gas measured in between two coils in the upper part of the section $T_{\mathrm{g}}^{\mathrm{coil}, 12}$.
Temperature of the air supplied into the combustion chamber was measured at $20^{\circ} \mathrm{C}$ for each experimental test.

Based on the chemical composition of the fuel (Table 3) and the mass flow rates of the fuel and air (Table 7), the flue gas composition was determined. Calculated mole fractions of the exhaust gases for each experimental test case are given in Table 8.

Table 6 Input geometrical data

\begin{tabular}{cccc}
\hline Parameter & Value & Parameter & Value \\
\hline$D_{b} / \mathrm{m}$ & 0.69 & $d / \mathrm{m}$ & 0.027 \\
$H / \mathrm{m}$ & 1.1 & $\varphi / \mathrm{m}$ & 0.027 \\
$D_{1} / \mathrm{m}$ & 0.43 & $N_{1}$ & 30 \\
$D_{2} / \mathrm{m}$ & 0.57 & $N_{2}$ & 29 \\
\hline
\end{tabular}

Table 7 Experimental data of laboratory-scale boiler

\begin{tabular}{ccccccc}
\hline Parameter & \multicolumn{6}{c}{ Test No. } \\
\cline { 2 - 7 } & 1 & 2 & 3 & 4 & 5 & 6 \\
\hline$\dot{m}_{\text {fuel }} / \mathrm{kg} \cdot \mathrm{h}^{-1}$ & 5.1 & 5.1 & 5.2 & 5.2 & 6.4 & 6.4 \\
$\dot{m}_{\text {air }} / \mathrm{kg} \cdot \mathrm{h}^{-1}$ & 50.8 & 49.9 & 53.0 & 53.4 & 45.1 & 53.5 \\
$\dot{m}_{1} / \mathrm{kg} \cdot \mathrm{h}^{-1}$ & 542.7 & 751.3 & 732.7 & 539.3 & 545.6 & 556.9 \\
$T_{1}^{\text {in }} /{ }^{\circ} \mathrm{C}$ & 96.8 & 93.1 & 108.8 & 108.2 & 106.8 & 114.2 \\
$T_{1}^{\text {out }} /{ }^{\circ} \mathrm{C}$ & 151.7 & 135.5 & 159.9 & 170.8 & 171.9 & 184.7 \\
$T_{\mathrm{g}}^{\text {coil, } 12} /{ }^{\circ} \mathrm{C}$ & 402.2 & 393.4 & 392.6 & 395.3 & 430.7 & 454.9 \\
$T_{\mathrm{g}}^{\text {out }} /{ }^{\circ} \mathrm{C}$ & 148.1 & 142.6 & 153.4 & 159.4 & 151.1 & 162.9 \\
$\dot{Q} / \mathrm{kW}$ & 18.7 & 19.7 & 23.9 & 20.7 & 22.8 & 25.6 \\
$\lambda$ & 1.96 & 1.93 & 2.01 & 2.01 & 1.39 & 1.65 \\
$\eta / \%$ & 68.0 & 71.0 & 84.0 & 77.0 & 66.0 & 74.0 \\
\hline
\end{tabular}

Table 8 Flue gas composition (vol\%)

\begin{tabular}{ccccc}
\hline Test No. & $\mathrm{H}_{2} \mathrm{O}$ & $\mathrm{CO}_{2}$ & $\mathrm{O}_{2}$ & $\mathrm{~N}_{2}$ \\
\hline 1 & 7.54 & 10.12 & 9.50 & 72.84 \\
2 & 7.67 & 10.29 & 9.30 & 72.74 \\
3 & 7.38 & 9.91 & 9.74 & 72.97 \\
4 & 7.33 & 9.84 & 9.81 & 73.01 \\
5 & 10.32 & 13.86 & 5.25 & 70.57 \\
6 & 8.85 & 11.88 & 7.49 & 71.77 \\
\hline
\end{tabular}

The computations were performed in two steps:

(1) step I: the flue gas temperature at the inlet into the heat recovery section was assumed adiabatic $T_{\mathrm{g}}^{\mathrm{in}}=T_{\mathrm{ad}}$, which is derived from Eq. (5) and using Newton's iterative method, the temperatures of gas at the outlet $T_{\mathrm{g}}^{\text {out }}$ and in between the coils $T_{\mathrm{g}}^{\text {coil, 12 }}$, as well as the inlet oil temperature $T_{1}^{\text {in }}$ were 
calculated.

(2) step II: the procedure for step I is applied when taking into account the heat losses $\left(\dot{Q}_{\mathrm{a}}\right)$ of $3 \%$ of fuel chemical energy.

The computation results are summarized and compared with the corresponding experimental data in Table 9. Those marked with "Calc. .)" represent the step I results, whereas those marked with "Calc. ${ }^{2) "}$ refer to the results derived from step II computation. As seen, the resulting inlet oil temperature $T_{1}^{\text {in }}$ for each test case is higher compared to measurement data, and so is the gas temperature in between the inner (annular) and outer coil $T_{\mathrm{g}}^{\text {coil,12 }}$. The calculated outlet gas temperature $T_{\mathrm{g}}^{\text {out }}$ varies around the experimental value. The numerically obtained temperature values are essentially in satisfactory agreement with experimental data. As regards $T_{\mathrm{g}}^{\text {out }}$, the relative differences between model predictions and measured values for both the step I and step II calculations vary from $\sim 1 \%$ to $\sim 3 \%$. As far as $T_{1}^{\text {in }}$ values are concerned, these differences are higher and remained at the level of $10 \%$ on average. The calculated values of $T_{\mathrm{g}}^{\text {coil,12 }}$ are in general closer to those experimentally-derived and differ by maximum $8 \%$ (for test No. 4 for step I). On the other hand, the use of the second approach (step II) leads to obtaining oil temperature at the inlet into the HE section $T_{1}^{\text {in }}$ higher than the one resulting from the step I procedure, which in consequence leads to obtaining lower heat capacity. The calculated exemplary steady-state temperature distribution of both media, flue gases and oil, along the considered heat exchanger for the case simulating experimental test No. 6 (Table 7) is displayed in Fig. 8.

The experimental values of inlet and outlet media temperatures were also depicted (filled points). As seen, the total temperature decrease of exhaust gases exceeds $1220^{\circ} \mathrm{C}$. Consequently, the total increase of oil temperature reaches the level of approximately $63^{\circ} \mathrm{C}$.

Fig. 9 shows the change in Reynolds number of flue gases and oil flows for this case. Obviously, an increasing tendency with increasing temperature observed for thermal oil results from the viscosity decrease of this medium.

Table 9 Comparison of experimental and calculation results with determined errors

\begin{tabular}{|c|c|c|c|c|c|c|c|c|c|c|c|}
\hline \multirow{2}{*}{ Parameter } & Exp. & (alc. $^{1)}$ & Error/\% & Calc. $^{2)}$ & Error $/ \%$ & \multirow{2}{*}{ Parameter } & Exp. & (alc. ${ }^{1)}$ & Error/\% & Calc. $^{2)}$ & Error $/ \%$ \\
\hline & \multicolumn{5}{|c|}{ Test No. 1} & & \multicolumn{5}{|c|}{ Test No. 4} \\
\hline$T_{\mathrm{g}}^{\text {out }} /{ }^{\circ} \mathrm{C}$ & 148.1 & 144.6 & 2.4 & 144.8 & 2.2 & $T_{\mathrm{g}}^{\text {out }} /{ }^{\circ} \mathrm{C}$ & 159.4 & 158.0 & 0.9 & 158.4 & 0.6 \\
\hline$T_{1}^{\text {in }} /{ }^{\circ} \mathrm{C}$ & 96.8 & 107.1 & 10.6 & 108.0 & 11.6 & $T_{1}^{\text {in }} /{ }^{\circ} \mathrm{C}$ & 108.2 & 118.8 & 9.8 & 119.9 & 10.8 \\
\hline$T_{1}^{\text {out }} /{ }^{\circ} \mathrm{C}$ & 151.7 & 151.7 & - & 151.7 & - & $T_{1}^{\text {out }} /{ }^{\circ} \mathrm{C}$ & 170.8 & 170.8 & - & 170.8 & - \\
\hline$\dot{Q} / \mathrm{kW}$ & 18.7 & 18.2 & 2.7 & 17.6 & 5.9 & $\dot{Q} / \mathrm{kW}$ & 20.7 & 18.5 & 10.6 & 17.9 & 13.5 \\
\hline$T_{\mathrm{g}}^{\mathrm{in}} /{ }^{\circ} \mathrm{C}$ & - & 1232.4 & - & 1199.9 & - & $T_{\mathrm{g}}^{\mathrm{in}} /{ }^{\circ} \mathrm{C}$ & - & 1205.4 & - & 1173.5 & - \\
\hline \multirow[t]{2}{*}{$T_{\mathrm{g}}^{\mathrm{coil}, 12 /{ }^{\circ} \mathrm{C}}$} & 402.2 & 413.0 & 2.7 & 408.0 & 1.4 & $T_{\mathrm{g}}^{\mathrm{coil}, 12} /{ }^{\circ} \mathrm{C}$ & 395.3 & 427.1 & 8.1 & 422.0 & 6.8 \\
\hline & \multicolumn{5}{|c|}{ Test No. 2} & & \multicolumn{5}{|c|}{ Test No. 5} \\
\hline$T_{\mathrm{g}}^{\text {out }} /{ }^{\circ} \mathrm{C}$ & 142.6 & 138.5 & 2.9 & 138.5 & 2.9 & $T_{\mathrm{g}}^{\text {out }} /{ }^{\circ} \mathrm{C}$ & 151.1 & 154.7 & 2.4 & 155.1 & 2.7 \\
\hline$T_{1}^{\mathrm{in}} /{ }^{\circ} \mathrm{C}$ & 93.1 & 103.7 & 11.4 & 104.3 & 12.0 & $T_{1}^{\text {in }} /{ }^{\circ} \mathrm{C}$ & 106.8 & 118.6 & 11.1 & 119.5 & 11.9 \\
\hline$T_{1}^{\text {out }} /{ }^{\circ} \mathrm{C}$ & 135.5 & 135.5 & - & 135.5 & - & $T_{1}^{\text {out }} /{ }^{\circ} \mathrm{C}$ & 171.9 & 171.9 & - & 171.9 & - \\
\hline$\dot{Q} / \mathrm{kW}$ & 19.7 & 18.3 & 7.1 & 17.7 & 6.9 & $\dot{Q} / \mathrm{kW}$ & 22.9 & 21.8 & 4.8 & 21.2 & 7.4 \\
\hline$T_{\mathrm{g}}^{\mathrm{in}} /{ }^{\circ} \mathrm{C}$ & - & 1248.4 & - & 1215.5 & - & $T_{\mathrm{g}}^{\mathrm{in}} /{ }^{\circ} \mathrm{C}$ & - & 1562.2 & - & 1522.4 & - \\
\hline \multirow[t]{2}{*}{$T_{\mathrm{g}}^{\mathrm{coil}, 12 /{ }^{\circ} \mathrm{C}}$} & 393.4 & 402.1 & 2.2 & 397.1 & 0.9 & $T_{\mathrm{g}}^{\mathrm{coil}, 12} /{ }^{\circ} \mathrm{C}$ & 430.7 & 449.5 & 4.4 & 445.0 & 3.3 \\
\hline & \multicolumn{5}{|c|}{ Test No. 3} & & \multicolumn{5}{|c|}{ Test No. 6} \\
\hline$T_{\mathrm{g}}^{\text {out }} /{ }^{\circ} \mathrm{C}$ & 153.4 & 156.9 & 2.3 & 157.1 & 2.4 & $T_{\mathrm{g}}^{\text {out }} /{ }^{\circ} \mathrm{C}$ & 162.9 & 165.8 & 1.8 & 166.3 & 2.1 \\
\hline$T_{1}^{\text {in }} /{ }^{\circ} \mathrm{C}$ & 108.8 & 120.6 & 10.9 & 121.4 & 11.6 & $T_{1}^{\text {in }} /{ }^{\circ} \mathrm{C}$ & 114.2 & 121.6 & 6.5 & 128.8 & 7.5 \\
\hline$T_{1}^{\text {out }} /{ }^{\circ} \mathrm{C}$ & 159.9 & 159.9 & - & 159.9 & - & $T_{1}^{\text {out }} /{ }^{\circ} \mathrm{C}$ & 184.7 & 184.7 & - & 184.7 & - \\
\hline$\dot{Q} / \mathrm{kW}$ & 23.9 & 18.6 & 22.2 & 18.0 & 24.7 & $\dot{Q} / \mathrm{kW}$ & 25.6 & 22.4 & 12.5 & 21.7 & 15.2 \\
\hline$T_{\mathrm{g}}^{\mathrm{in}} /{ }^{\circ} \mathrm{C}$ & - & 1212.0 & - & 1180.0 & - & $T_{\mathrm{g}}^{\mathrm{in}} /{ }^{\circ} \mathrm{C}$ & - & 1394.3 & - & 1358.2 & - \\
\hline$T_{\mathrm{g}}^{\mathrm{coil}, 12 /{ }^{\circ} \mathrm{C}}$ & 392.6 & 420.0 & 7.0 & 414.8 & 5.7 & $T_{\mathrm{g}}^{\mathrm{coil}, 12} /{ }^{\circ} \mathrm{C}$ & 454.9 & 466.4 & 2.5 & 461.1 & 1.4 \\
\hline
\end{tabular}

Noted: ${ }^{1)} T_{\mathrm{g}}^{\text {in }}=T_{\text {ad }}, \dot{Q}_{\mathrm{a}}=0 ;{ }^{2)} T_{\mathrm{g}}^{\text {in }}=T_{\text {ad }}, \dot{Q}_{\mathrm{a}}=0.03 \cdot \dot{Q}_{\mathrm{CH}}$ 


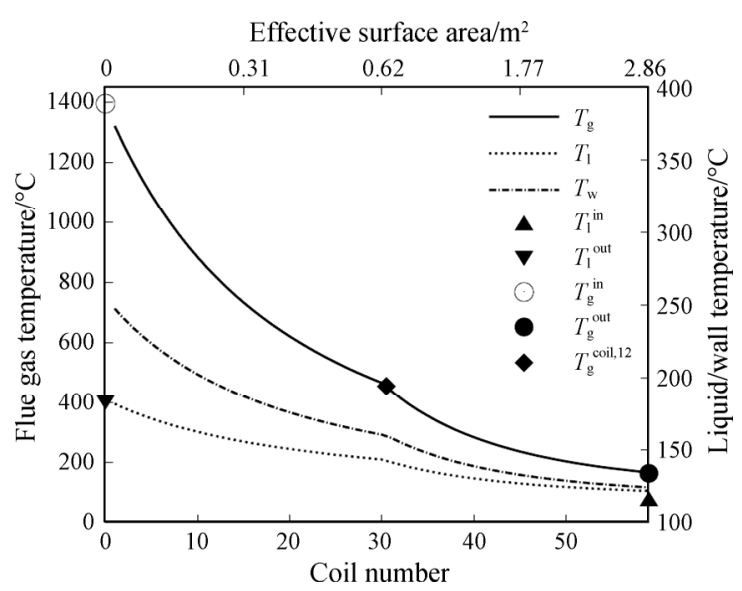

Fig. 8 The simulated temperature change of flue gases and oil and calculated inlet gas temperature (point filled with white); points filled with black - experimental data (test No. 6)

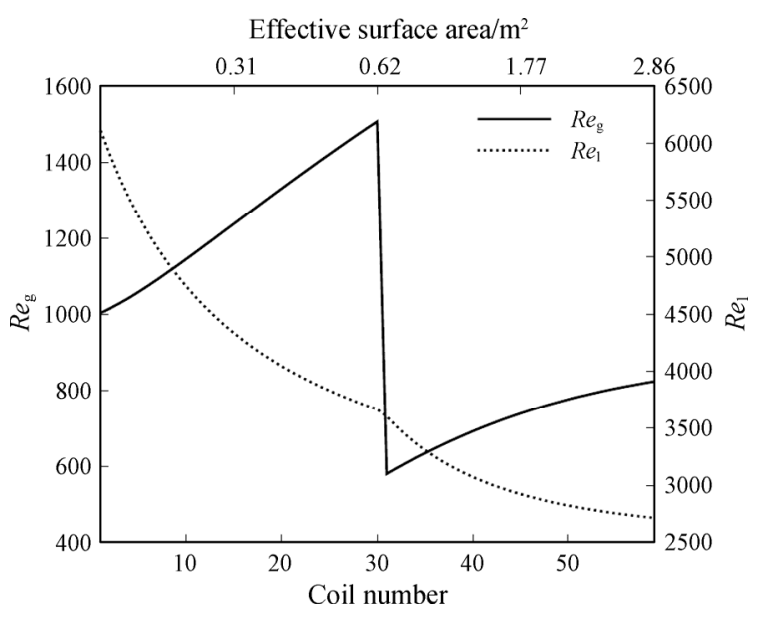

Fig. 9 Computed change of $R e$ along the exchanger (test No. 6)

The Reynolds number for flue gas flow follows a reverse pattern, i.e. it increases with decreasing temperature which is due to decreased gas viscosity. The $R e$ number changes within the range between 500 and 1500 for flue gas flow and from 2750 to 6250 for oil flow.

As expected, the less intensive heat exchange appears in the area of lower media temperatures, which is illustrated by the change curves of heat transfer coefficients for both media, $\alpha_{\mathrm{g}}$ and $\alpha_{1}$ in Fig. 10 (compared with Fig. 8). These vary between medium inlet and outlet, within the range of $\sim 60$ and $\sim 17 \mathrm{~W} /\left(\mathrm{m}^{2} \cdot \mathrm{K}\right)$ on the flue gas-side and from $\sim 450$ to $\sim 750 \mathrm{~W} /\left(\mathrm{m}^{2} \cdot \mathrm{K}\right)$ on the oil-side. Sudden increase/decrease of the $\operatorname{Re}$ and $\alpha$ values is associated with the geometry change, i.e. with the passage between the coils. Also, as shown in Fig. 11, the heat exchange is more efficient in the internal coil rather than in the outer coil. In the former section, the heat of $17 \mathrm{~kW}$ is exchanged, whereas in the second one it is only $5.4 \mathrm{~kW}$. Therefore, the total heat capacity equals $22.4 \mathrm{~kW}$.

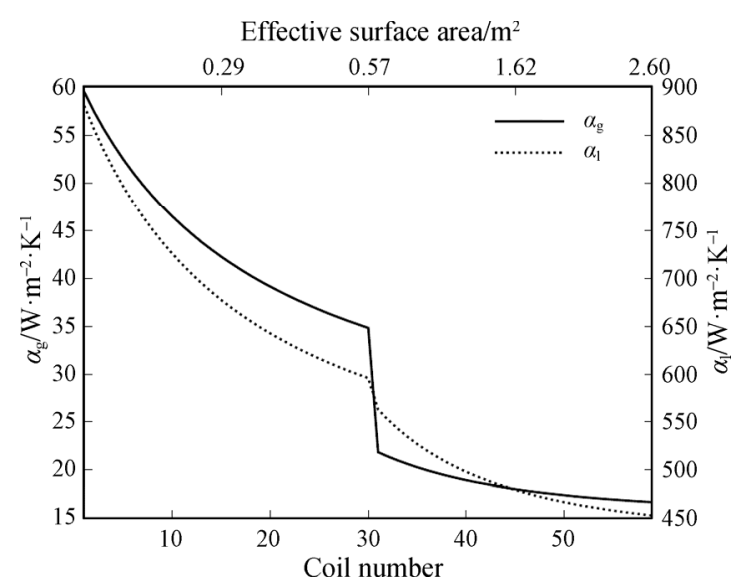

Fig. 10 The calculated distribution of heat transfer coefficient along the exchanger (test No. 6)

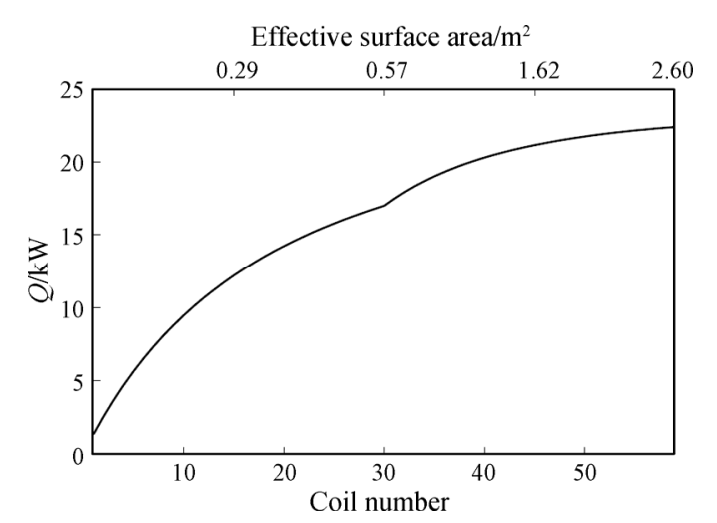

Fig. 11 The calculated heat exchange along the exchanger (test No. 6)

\section{Conclusions}

The multi-section lumped model was developed to describe the thermal performance of small-scale helically coiled biomass-fueled boiler designed to operate with the ORC power generation unit. The model allows relatively fast calculations with satisfactory accuracy and is proved to be a reliable tool in predicting the operation parameters of boilers with heat recovery sections of complex geometry. It therefore may be an alternative for costly and time-consuming CFD calculations.

The model may be applied twofold:

(1) in the designing process - the procedure in this case assumes the gas temperature at the inlet into the heat exchange section of a boiler to be adiabatic.

(2) to verify the thermal characteristics of existing device - in this case the inlet flue gas temperature is derived based on the thermal balance accounting for assumed heat losses and checking the agreement between computed and experimental values of the cooling media inlet temperature. Thus, the advantage of this approach is the possibility to determine the temperature in the 
difficult-to- measure areas (e.g., flue gases entering the heat recovery section).

The model developed was verified with the use of measurement data from a laboratory-scale thermal-oil boiler fed with biomass. The discrepancies between computation results and experimental data are at maximum level of $12 \%$, which may be due to the heat transfer correlations used. Therefore, the additional analyses are needed to be performed.

\section{Acknowledgements}

This work was financially supported by a National Project POIG.01.01.02-00-016/08 "Model of agroenergy complexes as an example of distributed cogeneration based on a local renewable energy sources".

\section{References}

[1] Mikielewicz J., Bykuć S., Mikielewicz D., Application of renewable energy sources to drive Organic Rankine Cycle micro CHP. Proceeding of Heat Transfer and Renewable Sources of Energy, Międzyzdroje, Poland, 2006, pp. 329-336.

[2] Caposciutti G., Antonelli M., Experimental investigation on air displacement and air excess effect on $\mathrm{CO}, \mathrm{CO}_{2}$ and $\mathrm{NO}_{x}$ emissions of a small size fixed bed biomass boiler. Renewable Energy, 2018, 116: 795-804.

[3] Mascuch J., Novotny V., Vodicka V., Spale J., Zeleny Z., Experimental development of a kilowatt-scale biomass fired micro-CHP unit based on ORC with rotary vane expander. Renewable Energy, 2020, 147(3): 2882-2895.

[4] http://orc-world-map.org/.

[5] Prabhanjan D.G., Ragbavan G.S.V., Kennic T.J., Comparison of heat transfer rates between a straight tube heat exchanger and a helically coiled heat exchanger. International Communication in Heat and Mass Transfer, 2002, 29(2): 185-191.

[6] Beigzadeh R., Rahimi M., Parvizi M., Experimental study and genetic algorithm-based multi-objective optimization of thermal and flow characteristics in helically coiled tubes. Heat and Mass Transfer, 2013, 49: 1307-1318.

[7] Aria H., Akhavan-Behabadi M.A., Shemirani F.M., Experimental investigation on flow boiling heat transfer and pressure drop of HFC-134a inside a vertical helically coiled tube. Heat Transfer Engineering, 2012, 33(2): 79-87.

[8] Wang C., Sun B., Lin W., He F., You Y., Yu J., Turbulent convective heat transfer of methane at supercritical pressure in a helical coiled tube. Journal of Thermal Science, 2018, 27(1): 55-63.

[9] Pawar S.S., Sunnapwar V.K., Experimental and CFD investigation of convective heat transfer in helically coiled tube heat exchanger. Chemical Engineering Research and Design, 2014, 92: 2294-2312.

[10] Niu X., Luo S., Fan L.L., Zhao L., Numerical simulation on the flow and heat transfer characteristics in the one-side heating helically coiled tubes. Applied Thermal Engineering, 2016, 106: 579-587.

[11] Jayakumar J.S., Mahajani S.M., Mandal J.C., Iyer K.N., Vijayan P.K., CFD analysis of single-phase flows inside helically coiled tubes. Computers \& Chemical Engineering, 2010, 34: 430-446.

[12] Patil R.H., Isothermal laminar fluid flow in spiral tube coils. Heat and Mass Transfer, 2018, 54: 3673-3693.

[13] Sharafeldeen M.A., Berbish N.S., Moawed M.A., Ali R.K., Experimental investigation of heat transfer and pressure drop of turbulent flow inside tube with inserted helical coils. Heat and Mass Transfer, 2017, 53: 12651276.

[14] Poskas P., Poskas R., Experimental investigation of local heat transfer and skin friction in tube coils. Journal of Thermal Science, 2002, 11(3): 235-240.

[15] Gomma A., Aly W.I.A., Omara M., Abdelmagied M., Correlations for heat transfer coefficient and pressure drop in the annulus of concentric helical coils. Heat and Mass Transfer, 2014, 50: 583-586.

[16] Rennie T.J., Raghavan V.G.S., Experimental studies of a double-pipe helical heat exchanger. Experimental Thermal and Fluid Science, 2005, 29: 919-924.

[17] Jayakumar J.S., Mahajani S.M., Mandal J.C., Vijayan P.K., Bhoi R., Experimental and CFD estimation of heat transfer in helically coiled heat exchangers. Chemical Engineering Research and Design, 2008, 86: 221-232.

[18] Clay A., Tansley G.D., Exploration of a simple, low cost, micro gas turbine recuperator solution for a domestic combined heat and power unit. Applied Thermal Engineering, 2011, 31: 2676-2684.

[19] Sogni A., Chiesa P., Calculation code for helically coiled heat recovery boilers. Energy Procedia, 2014, 45: 492-501.

[20] Hassanzadeh B., Keshavarz A., Ebrahimi M., Heat transfer simulation in a helically coiled tube steam generator. Heat and Mass Transfer, 2014, 50: 13-21.

[21] Collazo J., Porteiro J., Miguez J.L., Granada E., Gomez M.A., Numerical simulation of a small-scale biomass boiler. Energy Conversion and Management, 2012, 64: 89-96.

[22] Zhang X., Chen Q., Bradford R., Sharifi V., Swithenbank J., Experimental investigation and mathematical modelling of wood combustion in a moving grate boiler. Fuel Processing Technology, 2010, 91: 1491-1499.

[23] Comesana R., Collazo J., Miguez J.L., Porteiro J., CFD 
POLESEK-KARCZEWSKA Sylwia et al. Application of a lumped multi-section model for analyzing the thermal performance

Simulation of a Fixed Bed $60 \mathrm{~kW}$ Biomass Boiler. Proceeding of 18th European biomass conference and exhibition, Lyon, France, 2010, pp. 1327-1331.

[24] Kardaś D., Turzyński T., Wardach-Święcicka I., Ronewicz K., Combustion and heat exchange in biomass-based oil boiler. IMP PAN Gdańsk, 2014. (in Polish)

[25] Press W.H., Teukolsky S.A., Vetterling W.T., Flannery B.P., Numerical Recipes in Fortran 77-Second Edition. Cambridge University Press, 1992.

[26] Klein M., Heda Ł., Kluska J., Kazimierski P., Physicochemical analysis of wood pellets. Unpublished technical report, IMP PAN Gdańsk, 2013.

[27] Parikha J., Channiwala S.A., Ghosal G.K., A correlation for calculating HHV from proximate analysis of solid fuels. Fuel, 2005, 84: 487-494.

[28] Fluent Database Materials, ANSYS Fluent 12.0, 2009.

[29] Demichowicz-Pigoniowa J., Physicochemical calculations. PWN Warszawa, 1984. (in Polish)

[30] Marchewicz A., Stańko T., Properties of Shell Thermia Oil B. IMP PAN Gdańsk, 2010. (in Polish)

[31] Kalinowski E., Heat transfer and heat exchangers. Wrocław, Oficyna Wydawnicza Politechniki Wrocławskiej, 1995. (in Polish)

[32] Serth R.W., Lestina T.G., Process heat transfer: Principles, applications and rules of thumb. Amsterdam, Elsevier, 2007.

[33] Madejski J., Theory of heat exchange. Szczecin, Wydawnictwo Politechniki Szczecińskiej, 1998. (in Polish) 